\title{
Optimising dairy farm returns in summer-dry areas
}

\author{
K. ALEXANDER' and N. MOUTON ${ }^{2}$ \\ ${ }^{1}$ Farmer, Hikurangi, Whangarei \\ ${ }^{2}$ Agricultural Consultant, Hamilton
}

\begin{abstract}
To increase milk productivity on an SO-hectare dairy farm, a series of improvements was introduced. With the use of fodder flow analysis and step-by-step identification of each part of the farming process a system was introduced on the property to improve overall output. A new farm management system was introduced for the property: The system hinges around the use of annual ryegrass summer forage crops to achieve a change to a new ryegrass species, removing old swards of fescue and kikuyu. Improved soil fertility and use of nitrogen, together with a crop programme, helped change the grass growth curve. Having employed these processes of change, timing of management decisions and long-term planning were critical to any change of farm management. Deciding hew to implement a change and actually achieving the change were critical to the success of lifting milk production while maintaining overall profitability.
\end{abstract}

Keywords: dairy farms, decision making, farm management, fodder, nitrogen, profit, research

This paper was prepared with total farm production improvement in mind, that is, through the use of fertiliser, grass renewal, cow quality and fodder cropping to create an even 12-month cycle of fodder.

\section{Background}

We purchased an 85-hectare property in 1990 for the $1991 / 92$ dairy season, as a first farm on $50 \%$ sharemilking. The farm. located north of Whangarei on the western edge of the Hikurangi Swamp, totals some 80 hectares, with a total effective grassland area of 80 hectares of the total farm area of 85 hectares.

Soil types are varied, as is typical in Northland, consisting of Marua clay, Wakapara silty loam,.Wairua clay, Otonga clay and Wairua peaty loam. The Wairua clay dominates the property on the flat area while the hill consists primarily of Marua clay and Otonga clay.

The property was initially stocked with 185 cows with a breeding index of 127 and a reliability of $37 \%$.
Soil test results in 1988 show $\mathrm{pH}$ at 5.65, Olsen $\mathrm{P}$ at 32.5 , and potash at 7 , with no available sulphur result.

Production levels under previous ownership was 33000 to $38000 \mathrm{~kg}$ of milksolids.

In the $1991 / 92$ and $1992 / 93$ seasons we realised a balance needed to be achieved in our forage supply to feed the cows fully on a low cost grass basis, as the existing system was badly flawed. Too many cattle and too little feed at the wrong time prevented a reasonable per cow and per hectare production being achieved.

Although we had already started a programme of regrassing, capital fertiliser, improvements to the race and water system, and more subdivision, the timing for cropping and pasture management was critical.

\section{Farm management changes}

Using local farms' 7-year database, rainfall and temperature figures, and local dry matter yields, and the services of Nico Mouton, Agricultural Consultant, we took our farming system to bits and rebuilt it. Soil fertility underpinned the whole system. Since the 1991/ 92 season, when average Olsen $\mathrm{P}$ was 22 , we have consistently applied $75-80 \mathrm{~kg}$ phosphate per year. Olsen $P$ is now settled at 42. Potash levels are now settled at approximately 6.75-7.0 after annual applications of 80-100 kg, potash; and sulphur levels lifted from 7 to 20 after application of approximately $100 \mathrm{~kg}$ sulphur per annum (Table 1).

Over the preceding 5 years a 12 -month cycle showed major peaks and troughs in our pasture production and yields between 12.7 and 14 tonnes per annum, with slow growth rates from January being typical.

We devised a rotational plan, planting Tama annual ryegrass in the spring, followed by Wairoa brassica or turnips in spring, followed by the new perennial ryegrass sward in the autumn.

In this way we achieved high winter growth rates of up to $150 \mathrm{~kg}$ per hectare per day, with nitrogen applied on Tama, and good summer growth rates. Annual crop yields were 12-1 3 tonnes per hectare.

This changed our peaks and troughs of fodder flow.

We increased the use of nitrogen substantially in the $1993 / 94$ season from $50 \mathrm{~kg}$ to $103 \mathrm{~kg}$ per hectare and to $145 \mathrm{~kg}$ per hectare for the 1994/95 season.

Nitrogen was applied 4-weekly during the spring 
Table 1 Soil fertility data, fertiliser applied $(\mathrm{kg} / \mathrm{ha})$ and milksolids production $(\mathrm{kg})$ results for four seasons from 1991/92.

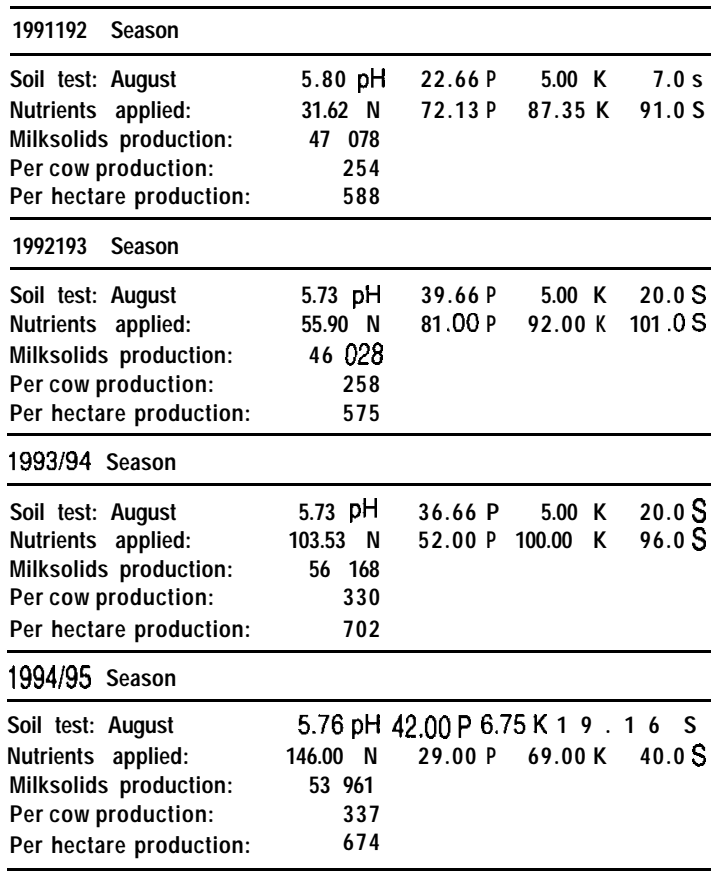

and early summer period to the end of December, and as soon as rain had fallen at the end of February through autumn and winter.

Although $8-10 \%$ of the land area was removed for spring crops, the application of nitrogen created excess silage surpluses which we harvested at 19/20 October with between $8-10 \%$ maximum heading.

In three of the seasons so far we have been able to achieve minimum ME levels of 10.5 , protein of $17 \%$ and ME levels in excess of 70 on unsiled material.

Yields increased to $56000 \mathrm{~kg}$ of milksolid in the 1993/94 season. Breeding index has improved to 132 with a reliability of $76 \%$.

\section{Sum mary}

We have identified a requirement to have an earlier calving date, mid point on and around 1 July.

- Drainage is a continuing limiting factor and needs investment.

- Winter milking or late summer milking is too high-a risk.

- Maximum days at 1.80 solids before 20 October.

- Other feeds, maize, silage, grains will be reviewed depending on price plus price effectiveness.

\section{Where to next?}

We have been able to change the pasture flow during the 12-month season using a variety of crops and nitrogen fertiliser. Many factors will decide future farm management practice. It is clear that the elements critical to obtaining maximum performance and return on this particular property are:

(a) Timing of decisions, planning out the farming system well in advance.

(b) Not losing sight of the all-important factor of producing the maximum farm surplus; we monitor our finances closely every month and annually compared with a group database, continually making profit-driven decisions.

Many options are being put forward to farmers at this time, such as variable milk pricing, irrigation systems and intensive feeding systems. But some of these systems are not yet proven, especially in Northland, and scientific data on a lot of these systems are sorely lacking.

Northland Dairy Co. should be congratulated on stimulating debate and initiating change, but the messages delivered were far from clear and detailed at times. We therefore look forward to further research in Northland in all these critical areas, and in our opinion, there is a lot of room in the system exists before jumping ship without sound reason. 